\title{
Alcohol Electrooxidation at Pt-Ru Sputter-deposited Electrode
}

\author{
Masahiko Shibamine Non-member (Nagaoka University of Technology) \\ Akifumi Yamada Non-member (Nagaoka University of Technology) \\ Minoru Umeda Member (Nagaoka University of Technology) \\ Shohji Tanaka Non-member (Ricoh Co., Ltd.)
}

Keywords: Pt-Ru electrode, sputtering, alcohol oxidation, direct alcohol fuel cells

The use of various alcohols including methanol has been considered as the fuel of direct alcohol fuel cells. Thus far, the Pt alloys have mainly been studied as anode electrocatalysts for fuel cells. $\mathrm{Pt}$ itself is poisoned by chemical species produced during the alcohol oxidation. There are many reports that the addition of $\mathrm{Ru}$ is effective for the alcohol oxidation. In this work, we will prepare Pt-Ru cosputtered electrode by changing Ru content, sputtering time and $\mathrm{Ar}$ pressure for the sputtering. By using the prepared electrocatalysts, the relationships between sputtering conditions and electrocatalytic activity were measured for methanol and ethanol.

An Au flag electrode was used as a sputter-deposition substrate, which has $8 \mathrm{~mm}$ diameter and $0.05 \mathrm{~mm}$ thick Au disk connected with $0.3 \mathrm{~mm}$ wire by a spot welding technique. On the Au electrode, electrocatalyst layer was formed by co-sputtering of $\mathrm{Pt}$ and $\mathrm{Ru}$. Electrochemical measurements were conducted by cyclic voltammetry (CV) in $0.5 \mathrm{~mol} \cdot \mathrm{dm}^{-3} \mathrm{H}_{2} \mathrm{SO}_{4}+1 \mathrm{~mol} \cdot \mathrm{dm}^{-3}$ alcohol solution. $\mathrm{An} \mathrm{Ag} / \mathrm{Ag}_{2} \mathrm{SO}_{4}$ and $\mathrm{Pt}$ coil were used as reference and counter electrodes, respectively. Energy dispersive X-ray spectroscopy (EDS) and XRD were conducted for the electrocatalyst characterization.

First, background CV was measured at Pt-Ru co-sputtered electrode in $0.5 \mathrm{~mol} \cdot \mathrm{dm}^{-3} \mathrm{H}_{2} \mathrm{SO}_{4}$. When $\mathrm{Ru}$ content increases, proton adsorption and desorption peaks which originates in Pt crystalline structure are disappeared. This confirms that Ru makes alloy with $\mathrm{Pt}$ in the co-sputtered electrode.

Next, methanol oxidation current density measured by $\mathrm{CV}$ at the Pt-Ru electrode in $0.5 \mathrm{~mol} \cdot \mathrm{dm}^{-3} \mathrm{H}_{2} \mathrm{SO}_{4}+1 \mathrm{~mol} \cdot \mathrm{dm}^{-3} \mathrm{CH}_{3} \mathrm{OH}$ is shown with respect to $\mathrm{Ru}$ content in Fig. 1. The maximum current density is recorded at the electrode containing 27 at.\% Ru.

Ethanol electrooxidation was also measured in $0.5 \mathrm{~mol} \cdot \mathrm{dm}^{-3}$ $\mathrm{H}_{2} \mathrm{SO}_{4}+1 \mathrm{~mol} \cdot \mathrm{dm}^{-3} \mathrm{C}_{2} \mathrm{H}_{5} \mathrm{OH}$. The maximum current density is observed at the electrode containing 45 at.\% as shown Fig. 2.

When the sputtering time is changed from 15 to 60 minutes, alcohol oxidation current density increases according to the increase in the sputtering time.

By changing the Ar pressure, Ru content decreased according to an increase in Ar pressure. The maximum current density observed at $\mathrm{Ar}$ pressure of $5 \mathrm{~Pa}$ for the alcohol oxidation.

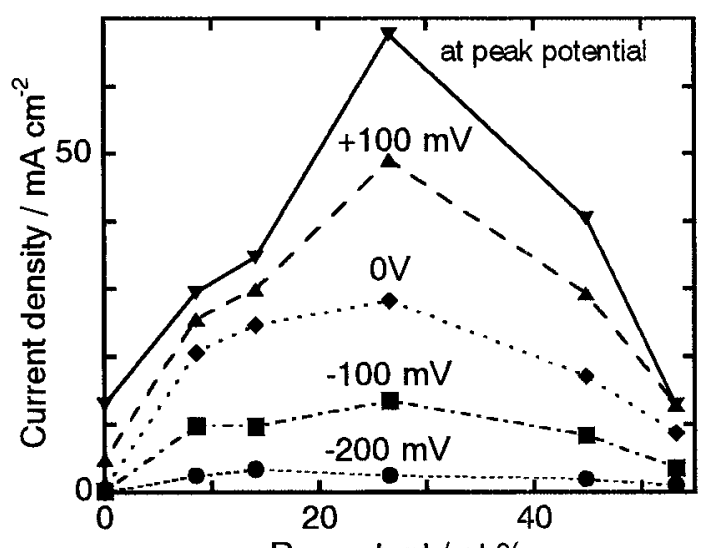

Ru content / at.\%

Fig. 1. Effect of Pt-Ru ratio on $\mathrm{CH}_{3} \mathrm{OH}$ oxidation

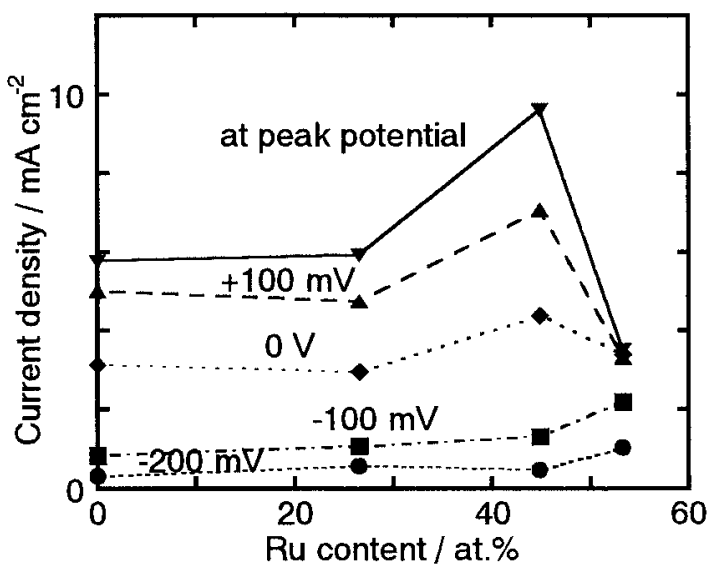

Fig. 2. Effect of Pt-Ru ratio on $\mathrm{C}_{2} \mathrm{H}_{5} \mathrm{OH}$ oxidation 


\title{
スパッタ法を用いて作製したPt-Ru電極のアルコール酸化反応
}

\author{
非会員 柴嶺 匡彦* 非会員 山田 明文* \\ 正 員 梅田 実* 非会員 田中 正治**
}

\author{
Alcohol Electrooxidation at Pt-Ru Sputter-deposited Electrode \\ Masahiko Shibamine*, Non-member, Akifumi Yamada*, Non-member, \\ Minoru Umeda*, Member, Shohji Tanaka**, Non-member
}

\begin{abstract}
The use of various alcohols including methanol has been considered as the fuel of direct alcohol fuel cells (DAFCs). Thus far, the Pt alloys have mainly been studied as anode electrocatalysts for DAFCs. Pt itself is poisoned by chemical species produced during the alcohol oxidation. There exist many reports that the addition of $\mathrm{Ru}$ is effective for the alcohol oxidation. In this work, we prepared Pt-Ru co-sputtered electrode by changing Ru content, sputtering time and Ar pressure for the sputtering. By using the prepared electrocatalysts, relationships between sputtering conditions and electrocatalytic activity were measured for some alcohols.
\end{abstract}

キーワード : Pt-Ru 電極, スパッタ法, アルコール酸化, 直接アルコール形燃料電池

Keywords: Pt-Ru electrode, sputtering, alcohol oxidation, direct alcohol fuel cells

\section{1. まえがき}

近年, 携帯用小型電子機器の多様化に伴い, エネルギー 効率が高く，環境への負荷が少ない直接アルコール形燃料 電池（DAFC）が大きな期待を集めている(1)。DAFC は燃 料として，メタノールをはじめとする各種アルコール水溶 液を直接使用するため, 小型・軽量化が容易に行える利点 がある。

その燃料電池用触媒としては, Pt 基合金が主に研究され ているが，メタノール酸化において，Pt は CO な゙のさま ざまな反応中間体が表面に強吸着し, 触媒活性を阻害する ことが知られている。この改良の目的から， Ruを Pt に添 加することで， $\mathrm{Ru}$ 上に吸着した $\mathrm{OH}$ などの含酸素種が反 応に寄与し，活性が向上するとの報告がある ${ }^{(2)} 。$

$\mathrm{Pt}-\mathrm{Ru}$ 触媒に関しては多くの研究が行われており ${ }^{(3) \sim(15)}$, その作成方法も従来は含浸法 ${ }^{(4) \sim(6)}$ やコロイド法 ${ }^{(7) \sim(10)}$ など を中心として研究されてきた。さらに最近では，小型然料

* 長岡技術科学大学物質 - 材料系

干 940-2188 長岡市上富岡町 1603-1

Department of Materials Science and Technology, Nagaoka University of Technology

1603-1, Kamitomioka, Nagaoka 940-2188

**（株）リコー 先端技術研究所 環境技術研究室

厂224-0035 横浜市都築区新栄町 16-1

Advanced Technology R\&D Center, Enviromental Technology Reserch Department, Ricoh Co., Ltd.

16-1, Shinei-cho,Tsuzuki-ku, Yokohama 224-0035
電池の研究開発に伴い, 触媒の新しい作成法も報告されて いる。特に, スパッ夕法 ${ }^{(11) \sim(15)}$ は組成や製膜時間などの制 御が容易なことから，大きな期待が寄せられている。しか しながら, 現在のところ粉体に対して触媒をスパッタする 技術は確立されているとは言いがたい。そこで我々は平板 基体を用いて，その上にスパッ夕法により電極触媒を作製 した。本研究ではスパッタ法による実用触媒作製を視野に 入れ，スパッ夕法を用いて作製した Pt-Ru 電極を用いて， $\mathrm{Pt}-\mathrm{Ru}$ 組成，スパッタ時間，スパッタ圧力，製膜する基盤 等の製膜条件とアルコール酸化反応について, 系統的に検 討した結果を報告する。

\section{2. 実験方法}

〈2・1 〉 電極基板の作製 スパッ夕製膜用の基板には $\mathrm{Au}$ フラッグ電極基板とグラッシーカーボン基板の二種類 を使用した。これらの電極基板を図 1 に示す。

$\mathrm{Au}$ フラッグ電極基板は直径 $8 \mathrm{~mm}$, 厚さ $0.05 \mathrm{~mm}$ の $\mathrm{Au}$ 䇴と直径 $0.3 \mathrm{~mm}$ の $\mathrm{Au}$ 線をスポット溶接し, 作製した。グ ラッシーカーボン基板は $1 \times 1 \mathrm{~cm}^{2}$ に切り出し, 表面を研 磨した。二種類の基板はアセトン, 超純水の順にそれぞれ 10 分間超音波洗浄を行った。

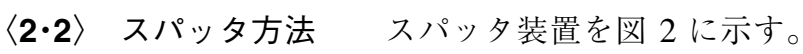
製膜する電極基板をスパッタ装置のホルダーに取り付け, $\mathrm{Ar}$ 雲囲気下で, ホルダーを回転させながら, Pt と Ruを 同時にスパッタすることで, $\phi 5 \mathrm{~mm}$ の電極触媒層を形成し た。スパッタした電極触媒層の厚さを検量線により算出し 


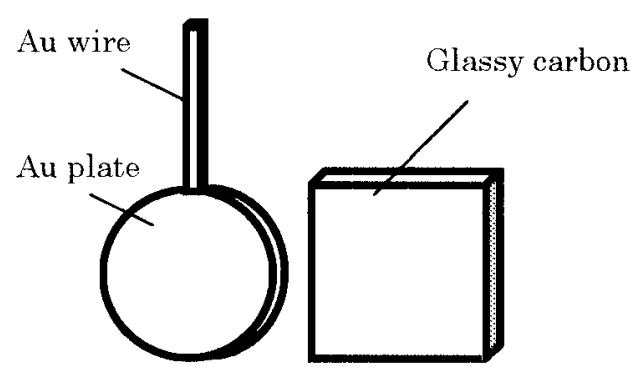

図 $1 \mathrm{Au}$ フラッグ電極基板とグラッシーカーボン基板

Fig. 1. Au flag and Glassy carbon electrode.

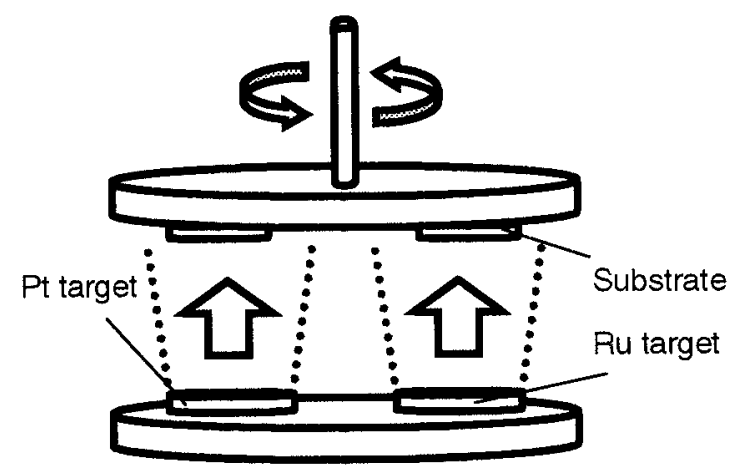

四 2 スパッ夕装置

Fig. 2. Sputtering apparatus.

表 1 スパッタ条件

Table 1. Sputtering condition.

\begin{tabular}{|c|c|}
\hline Item & Condition \\
\hline Ru content & Ru O at.\% - Ru 53 at.\% \\
\hline Ar pressure & $0.5 \mathrm{~Pa}-10 \mathrm{~Pa}$ \\
\hline Sputtering time & 15 min $-60 \mathrm{~min}$ \\
\hline Substrate & $\begin{array}{c}\text { Au flag electrode } \\
\text { Glassy carbon electrode }\end{array}$ \\
\hline
\end{tabular}

たところ，1500 ̊̊から $6000 \AA ̊$ であった。このときのスパッ 夕製膜条件を表 1 に示す。Pt-Ru 組成を Ru 0 at.\%から Ru 53 at.\%，製膜時間を 15 分から 60 分，スパッ夕時の $\mathrm{Ar}$ 圧 力を $0.5 \mathrm{~Pa}$ から $10 \mathrm{~Pa}$ に変化させて, Pt-Ru 電極を作製し た。なお，ホルダー回転数は $10 \mathrm{rpm}$, 基板温度は常温に固 定した。

$\langle\mathbf{2} \cdot \mathbf{3}\rangle$ 電極のキャラクタリゼーション $\quad \mathrm{Pt}-\mathrm{Ru}$ 二元同 時スパッ夕膜の結晶性を調べるためにX 線回折装置 (XDD1, SHIMADZU）を用いて測定した。また, 走査型電子顕 微鏡（JSM-6060A，JEOL）付属のエネルギー分散 X 線分 析装置（JED-2300，JEOL）を用いて，約 $100 \mu \mathrm{m} \times 150 \mu \mathrm{m}$ の範囲において原子比の測定を行った。

$\langle\mathbf{2} \cdot \mathbf{4}\rangle$ 電気化学測定 電気化学測定としてサイクリッ クボルタンメトリー $(\mathrm{CV})$ を行った。CV装置図を図 3 に示 す。作用極に $\mathrm{Pt}-\mathrm{Ru}$ スパッ夕電極（幾何学面積: $0.16 \mathrm{~cm}^{2}$ ), 参照極に $\mathrm{Ag} / \mathrm{Ag}_{2} \mathrm{SO}_{4}$, そして対極には $\mathrm{Pt}$ 線を使用した。電 解質溶液は $0.5 \mathrm{~mol} \cdot \mathrm{dm}^{-3} \mathrm{H}_{2} \mathrm{SO}_{4}+1 \mathrm{~mol} \cdot \mathrm{dm}^{-3}$ Alcohol を

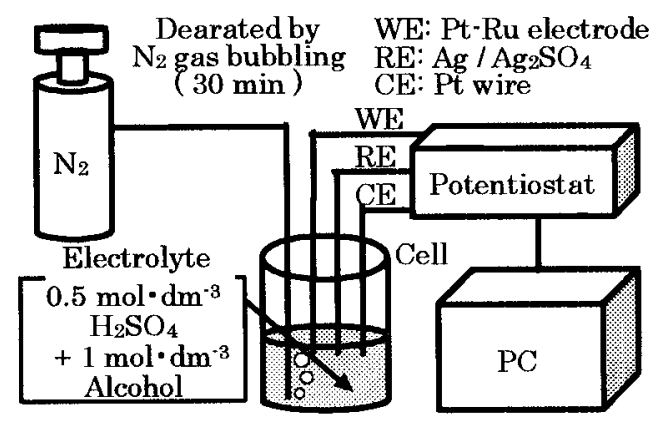

図 3 サイクリックボルタンメトリー (CV) 装置

Fig. 3. Schematic of cyclic voltammetry measurement.

用い，アルコールとしてメタノールとエタノールの二種類 を使用した。測定前に 30 分間窒素ガスでバブリングをす ることで溶存酸素の除去を行い, 測定は $10 \mathrm{mV} / \mathrm{s}$, 室温で 行った。なお，測定した電流は幾何学面積に対する電流密 度とした。

\section{3. 実験結果}

〈3・1 $\quad$ スパッタ製膜する電極基板の影響 基板に $\mathrm{Au}$ フラッグ電極とグラッシーカーボンの二種類を用い, 比較 した結果を図 4 に示す。これは Ru 45 at.\%の Pt-Ru 電極の バックグラウンド特性を示すが，基板によらずほぼ同じ結 果を示した。

また，この電極の $0.5 \mathrm{~mol} \cdot \mathrm{dm}^{-3} \mathrm{H}_{2} \mathrm{SO}_{4}+1 \mathrm{~mol} \cdot \mathrm{dm}^{-3}$ $\mathrm{CH}_{3} \mathrm{OH}$ 溶液中における $\mathrm{CV}$ を図 5 に示す。立ち上がりの 電位, 得られる電流密度ともにどちらの基板もほぼ同じ值 を示した。このことは $0.5 \mathrm{~mol} \cdot \mathrm{dm}^{-3} \mathrm{H}_{2} \mathrm{SO}_{4}+1 \mathrm{~mol} \cdot \mathrm{dm}^{-3}$ $\mathrm{C}_{2} \mathrm{H}_{5} \mathrm{OH}$ 溶液においても同様であった。

よって, バックグラウンド特性, アルコール酸化活性と もに電極基板には依存せず，Pt-Ru層と基板の間には相互 作用がないことが分かった。以上の結果より，本論文では $\mathrm{Au}$ フラッグ電極基板を用いることとした。

〈3.2〉 Pt-Ru 原子比依存性 Au フラッグ電極基板を 用いて，スパッ夕出力を変えて Pt-Ru 電極を作製した。こ れらの電極のアルコールを含まない, $0.5 \mathrm{~mol} \cdot \mathrm{dm}^{-3} \mathrm{H}_{2} \mathrm{SO}_{4}$ 溶液中での $-600 \mathrm{mV} \sim+800 \mathrm{mV}$ vs. $\mathrm{Ag} / \mathrm{Ag}_{2} \mathrm{SO}_{4}$ のバック グラウンド特性を示したものが図 6 である。Pt 単独の場合 においては， $-600 \mathrm{mV}$ から $-300 \mathrm{mV}$ 付近にかけて，Pt 表 面に水素が吸着または脱着する反応に起因した電流応答が はっきりと確認できるのに対し, Ru原子比が増加するにつ れて, この電流応答は徐々に不明膫になっている。このこ とから $\mathrm{Ru}$ 含有量が多くなると, $\mathrm{Pt}$ と $\mathrm{Ru}$ の合金化が進行 していることが分かる。

また，同じ電極の XRD 結果を示したものが図 7 である。 $2 \theta=46^{\circ}$ 付近で観測される Pt (200) に帰属されるピーク に注目すると, Ru 原子比の増加に伴い, 徐々に減少し, 次 第に観測されなくなる。このピークについて，ピーク角と 格子定数についてまとめたものを表 2 に示す。Ru 比が増加 するにつれて，ピーク位置が高角側にシフトしており，さ 


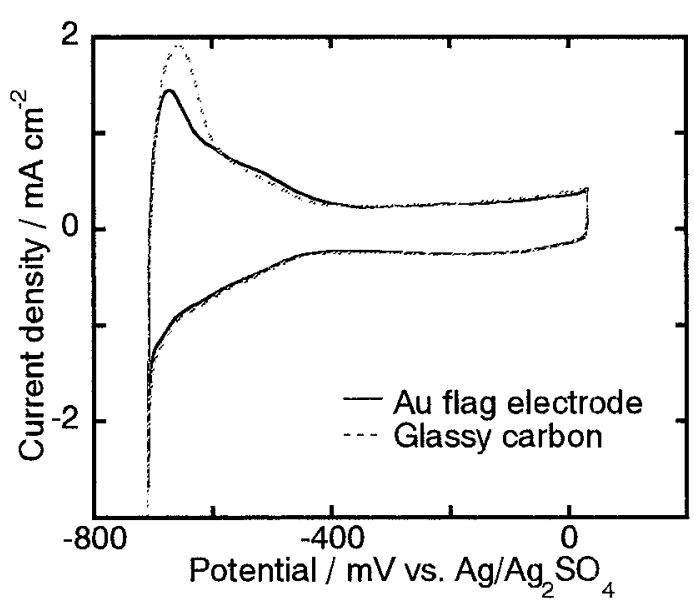

図 $4 \mathrm{Pt}: \mathrm{Ru}=55: 45$ の組成を持った電極の 硫酸中における CV（基板の影響）

Fig. 4. $\mathrm{CVs}$ at $\mathrm{Pt}: \mathrm{Ru}=55: 45$ atomic ratio electrodes in $0.5 \mathrm{~mol} \cdot \mathrm{dm}^{-3} \mathrm{H}_{2} \mathrm{SO}_{4}$ (Effect of sputtered substrate).

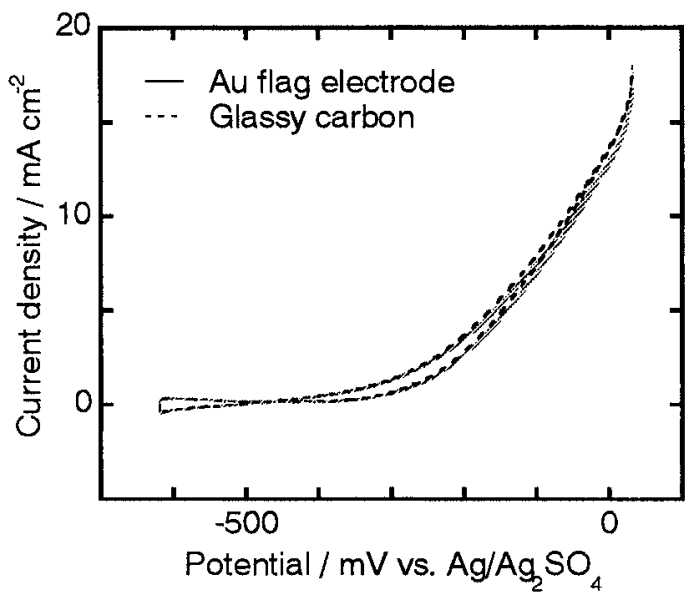

図 $5 \mathrm{Pt}: \mathrm{Ru}=55: 45$ の組成を持った電極の メタノール溶液中における CV (基板の影響)

Fig. 5. $\mathrm{CVs}$ at $\mathrm{Pt}: \mathrm{Ru}=55: 45$ atomic ratio electrodes in $1 \mathrm{~mol} \cdot \mathrm{dm}^{-3} \mathrm{CH}_{3} \mathrm{OH}+0.5 \mathrm{~mol} \cdot \mathrm{dm}^{-3} \mathrm{H}_{2} \mathrm{SO}_{4}$ (effect of sputtered substrate).

らに格子定数が減少していることが分かる。

現在のところ，白金ルテニウム合金については，十分研 究されている。 $\mathrm{Ru}$ 原子比が 0.7 以下では, $\mathrm{Pt}$ と $\mathrm{Ru}$ は固溶 体を形成し, $\mathrm{Ru}$ 原子が f.c.c. 構造の $\mathrm{Pt}$ 原子と置き換わる。 さらに $\mathrm{Pt}$ の金属半径 $0.139 \mathrm{~nm}$ に対して, $\mathrm{Ru}$ の金属半径は $0.133 \mathrm{~nm}$ と小さいため, $\mathrm{Ru}$ 原子比の増加に伴い，格子定 数は減少する。 $\mathrm{Ru}$ 原子比が 0.7 以上になると $\mathrm{Pt}$ が $\mathrm{Ru}$ の h.c.p. 構造の $\mathrm{Ru}$ 原子と置き換わるとの報告がある ${ }^{(16)}$ 。

よって, 本研究の XRD 結果からも Pt と Ru が合金化し ていることが支持される。

この電極を用いて $0.5 \mathrm{~mol} \cdot \mathrm{dm}^{-3} \mathrm{H}_{2} \mathrm{SO}_{4}+1 \mathrm{~mol} \cdot \mathrm{dm}^{-3}$ $\mathrm{CH}_{3} \mathrm{OH}$ 溶液中で $\mathrm{CV}$ を行った結果を図 8 に示す。横軸は 電極電位, 縦軸は電流密度である。 Ru 27 at.\%で最も大き な電流が得られた。

また, 図中の各電位における電流密度を, 原子比に対し

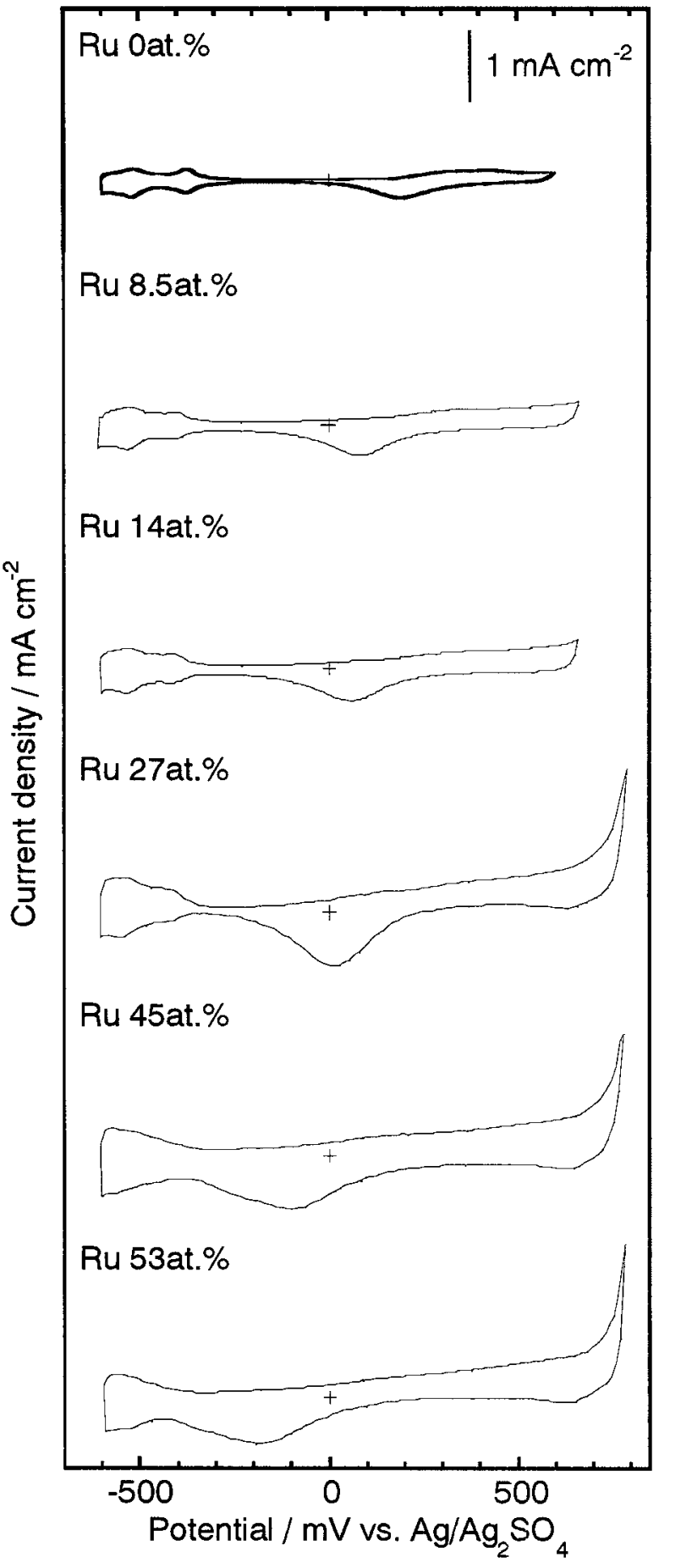

図 6 硫酸中での $\mathrm{CV}$ (Pt-Ru 原子比依存)

Fig. 6. CVs in $0.5 \mathrm{~mol} \cdot \mathrm{dm}^{-3} \mathrm{H}_{2} \mathrm{SO}_{4}$ (dependence of PtRu ratio).

てプロットしたものを図 9 に示す。Ru 27 at.\%までは Ru 比の増加に伴い, 得られる電流は単調に増加し, それ以降 では減少していることが分かる。これまでに Pt-Ru 組成は 50 at.\%が最も活性が高いとの報告もあり, 本研究の結果と は異なるが, これには触媒の形状, 形態, 結晶性などモル フォロジーも影響していると考えられ，それらが変化すれ ば最適組成も変わると推測される。 


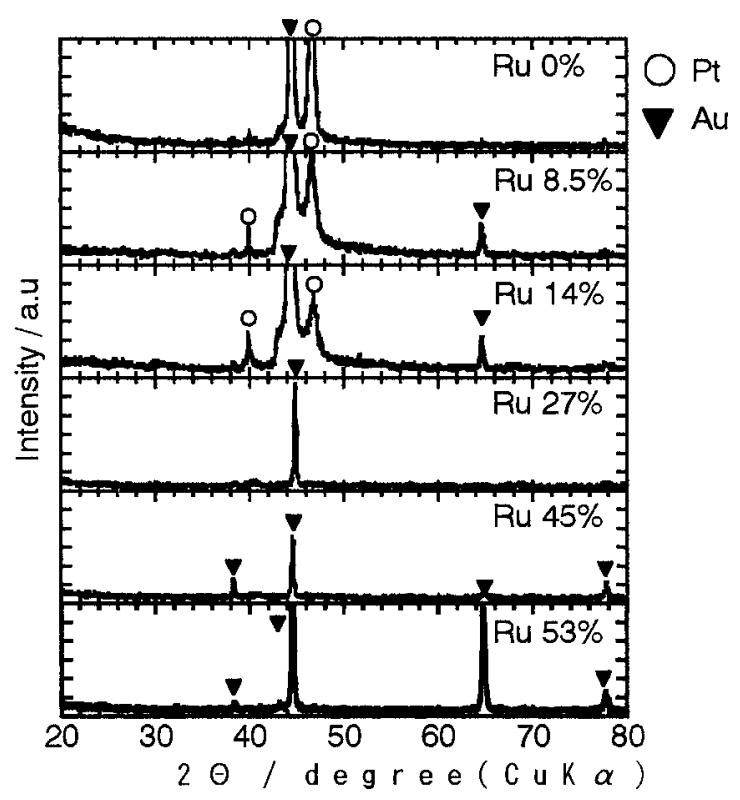

図 7 XRD 結果 (Pt-Ru 元素比依存)

Fig. 7. XRD analysis (dependence of Pt-Ru ratio).

表 2 Pt（200）に及ぼす Pt-Ru 元素比の影響

Table 2. Effect of Pt-Ru ratio on $\operatorname{Pt}(200)$.

\begin{tabular}{|c|c|c|}
\hline Ru content / at. \% & $2 \theta /$ degree (CuK $\alpha)$ & $\begin{array}{c}\text { Lattice } \\
\text { constant } / \mathrm{nm}\end{array}$ \\
\hline 0 & 46.616 & 0.3892 \\
\hline 8.5 & 46.743 & 0.3882 \\
\hline 14 & 46.828 & 0.3875 \\
\hline
\end{tabular}

同様にして, $0.5 \mathrm{~mol} \cdot \mathrm{dm}^{-3} \mathrm{H}_{2} \mathrm{SO}_{4}+1 \mathrm{~mol} \cdot \mathrm{dm}^{-3} \mathrm{C}_{2} \mathrm{H}_{5} \mathrm{OH}$ 溶液中での特性を示したものが図 10 である。 Ru 45 at.\%で 最大の電流密度が得られた。

$\langle\mathbf{3} \cdot \mathbf{3}\rangle$ スパッタ時間依存性、スパッ夕時間を変えて, $\mathrm{Pt}-\mathrm{Ru}$ 電極を作製した。なお，これらの電極は $\mathrm{Au}$ フラッグ 電極基板を用いており，さらに元素分析を行ったところ組成 は Ru 45 at.\%であることが分かった。これらの電極のバッ

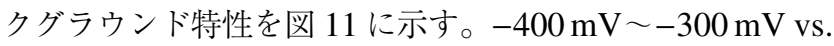
$\mathrm{Ag} / \mathrm{Ag}_{2} \mathrm{SO}_{4}$ では反応が起こらないので，この領域における 電流は二重層への充放電電流と考えられる。よって，この 二重層への充放電電流を比較すると, スパッ夕時間の増加 とともに電流が大きくなっており，電極表面の粗さが増し ていることが分かる。

これらの電極について, 先と同様にして $0.5 \mathrm{~mol} \cdot \mathrm{dm}^{-3}$ $\mathrm{H}_{2} \mathrm{SO}_{4}+1 \mathrm{~mol} \cdot \mathrm{dm}^{-3} \mathrm{CH}_{3} \mathrm{OH}$ 溶液中で $\mathrm{CV}$ を行った。そ の結果をまとめたものが図 12 である。スパッ夕時間の増加 に伴い, 得られる電流が単調に増加していることが分かる。 また, $0.5 \mathrm{~mol} \cdot \mathrm{dm}^{-3} \mathrm{H}_{2} \mathrm{SO}_{4}+1 \mathrm{~mol} \cdot \mathrm{dm}^{-3} \mathrm{C}_{2} \mathrm{H}_{5} \mathrm{OH}$ 溶液中 でも測定を行い, 同様の結果を得た。これは, バックグラ ウンド特性により，スパッ夕時間の増加に伴い電極面積が 増大していることが示されたので，そのためにアルコール 酸化活性が変化したものと推測される。

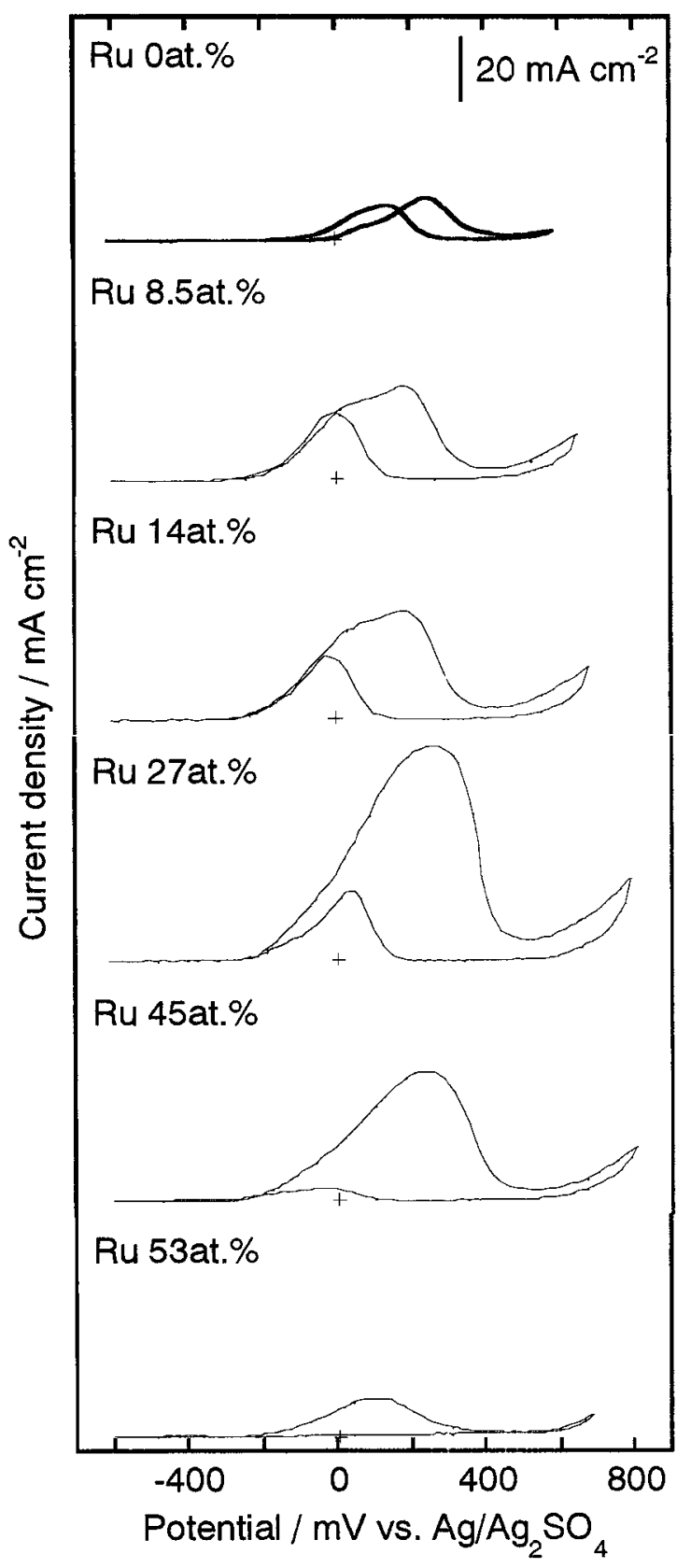

図 8 メ夕ノール溶液中での $\mathrm{CV}(\mathrm{Pt}-\mathrm{Ru}$ 原子比依存)

Fig. 8. $\mathrm{CVs}$ in $1 \mathrm{~mol} \cdot \mathrm{dm}^{-3} \mathrm{CH}_{3} \mathrm{OH}+0.5 \mathrm{~mol} \cdot \mathrm{dm}^{-3}$ $\mathrm{H}_{2} \mathrm{SO}_{4}$ (dependence of $\mathrm{Pt}-\mathrm{Ru}$ ratio).

〈3・4〉 スパッタ製膜時の Ar 圧力依存性 Au フラッ グ電極基板を用いて, スパッ夕製膜時の $\mathrm{Ar}$ 圧力を変化さ せ，Pt-Ru電極を作製した。この電極について元素分析を 行ったところ, Pt-Ru 原子比が変化することが分かった。し たがって，これらの電極からは純粋に $\mathrm{Ar}$ 圧力の影響を議 論することはできない。そこで, Pt-Ru 原子比を一定に固 定しながら, Ar 圧のみを変化させた電極を作製し, 評価を 行なった。

電極触媒の原子比が Ru $47 \pm 1.5$ at.\%とほぼ一定值を示す ようなサンプルを作製し，これらの電極についてのバック グラウンド特性を図 13 に示す。 


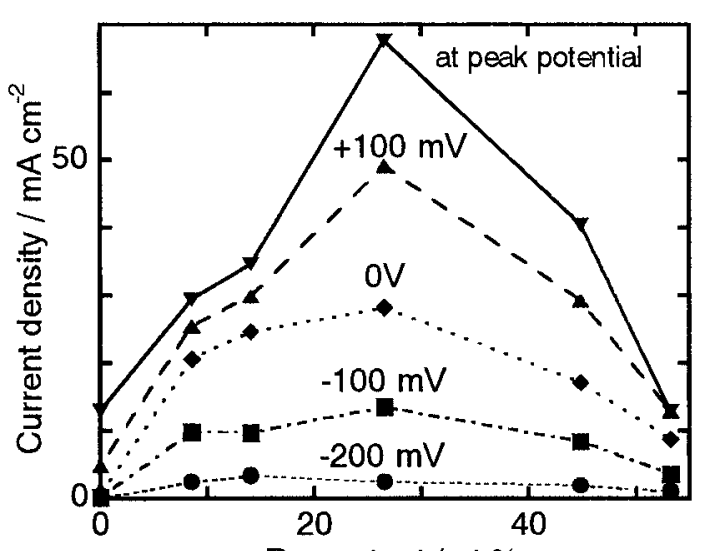

Ru content / at.\%

図 9 メ夕ノール酸化における Pt-Ru 原子比の影響

Fig. 9. Effect of Pt-Ru ratio on $\mathrm{CH}_{3} \mathrm{OH}$ oxidation.

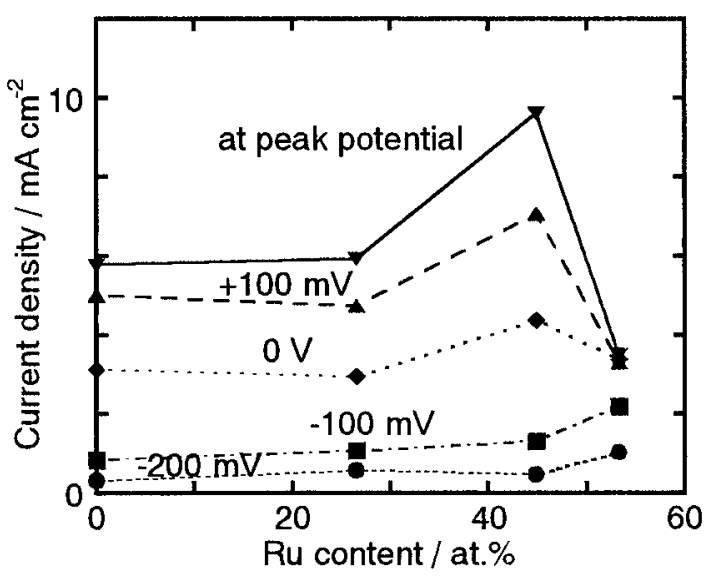

図 10 エタノール酸化における Pt-Ru 原子比の影響

Fig. 10. Effect of Pt-Ru ratio on $\mathrm{C}_{2} \mathrm{H}_{5} \mathrm{OH}$ oxidation.

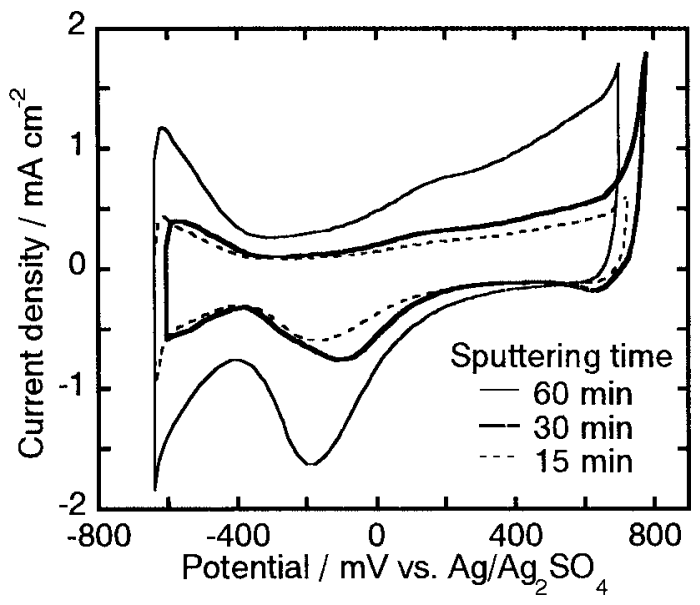

図 $11 \mathrm{Pt}: \mathrm{Ru}=55: 45$ の組成を持った電極の 硫酸中における CV（スパッ夕時間依存）

Fig. 11. CVs at $\mathrm{Pt}: \mathrm{Ru}=55: 45$ atomic ratio electrodes in $0.5 \mathrm{~mol} \cdot \mathrm{dm}^{-3} \mathrm{H}_{2} \mathrm{SO}_{4}$ (effect of sputtered substrate).

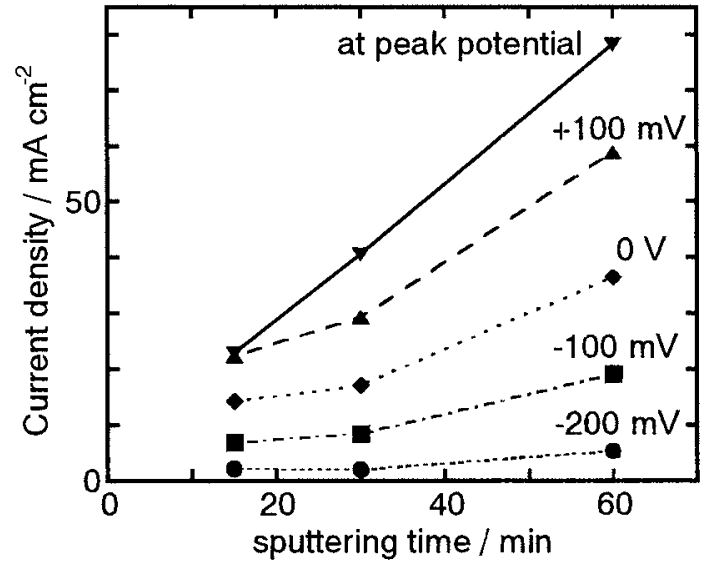

図 $12 \mathrm{Pt}: \mathrm{Ru}=55: 45$ の組成を持った電極の メタノール酸化におけるスパッ夕時間の影響

Fig. 12. Sputtering time dependence of current density at $\mathrm{Pt}: \mathrm{Ru}=55: 45$ atomic ratio electrodes in $1 \mathrm{~mol} \cdot \mathrm{dm}^{-3} \mathrm{CH}_{3} \mathrm{OH}+0.5 \mathrm{~mol} \cdot \mathrm{dm}^{-3} \mathrm{H}_{2} \mathrm{SO}_{4}$ as a function of electrode potential.

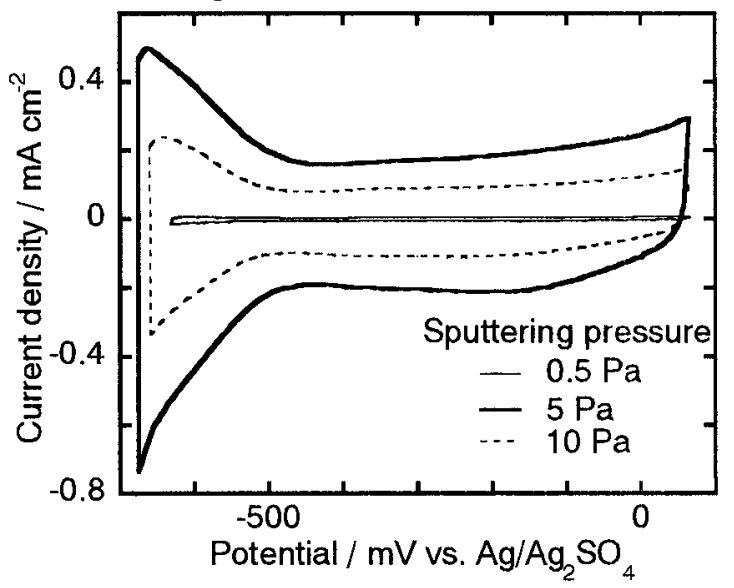

図 $13 \mathrm{Pt}: \mathrm{Ru}=53: 47$ の組成を持った電極の 硫酸中における CV（Ar 圧力依存）

Fig. 13. $\mathrm{CVs}$ at $\mathrm{Pt}: \mathrm{Ru}=53: 47$ atomic ratio electrodes in $0.5 \mathrm{~mol} \cdot \mathrm{dm}^{-3} \mathrm{H}_{2} \mathrm{SO}_{4}$ (effect of Ar pressure).

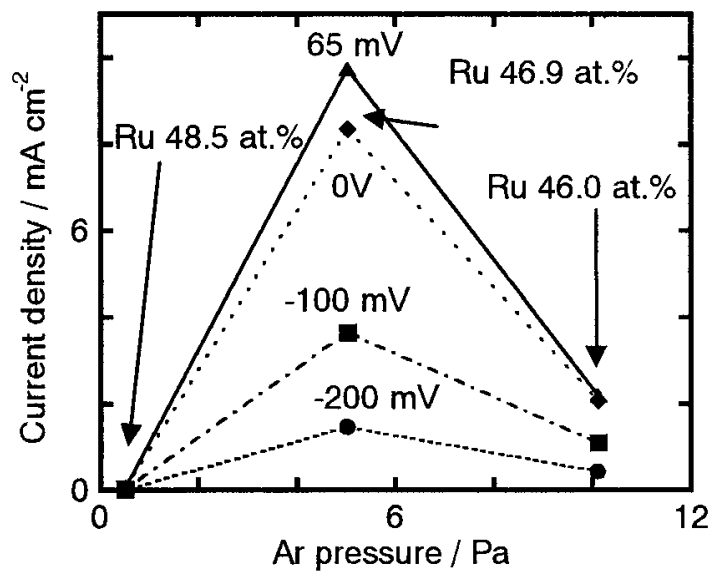

図 $14 \mathrm{Pt}: \mathrm{Ru}=53: 47$ の組成を持った電極の メタノール酸化における $\mathrm{Ar}$ 圧力の影響

Fig. 14. Ar pressure dependence of current density at $\mathrm{Pt}: \mathrm{Ru}=53: 47$ atomic ratio electrodes in $1 \mathrm{~mol} \cdot \mathrm{dm}^{-3}$ $\mathrm{CH}_{3} \mathrm{OH}+0.5 \mathrm{~mol} \cdot \mathrm{dm}^{-3} \mathrm{H}_{2} \mathrm{SO}_{4}$ as a function of electrode potential. 
先と同様にして, $-400 \mathrm{mV} \sim-300 \mathrm{mV}$ vs. $\mathrm{Ag} / \mathrm{Ag}_{2} \mathrm{SO}_{4}$ に 扮ける二重層への充放電電流を比較すると, $5 \mathrm{~Pa}, 10 \mathrm{~Pa}$, $0.5 \mathrm{~Pa}$ の順に充放電電流が大きくなっており, 表面の粗さ が増していることが分かる。表面粗さが増隇する理由とし ては，二つの理由が考えられる。一つは $\mathrm{Ar}$ 圧力を変えるこ とによって, 緻密な膜を形成し, これが粗さを小さくする 要因となることである。そしてもう一つは, Ar 圧力が低い ときには, ターゲットに衝突する $\mathrm{Ar}$ の量が少ないため, 堆 積する触媒量が減少し, 逆に Ar 圧力が高いときには, ター ゲットから飛び出した触媒粒子が過剩に存在する Arによっ て進路を妨げられるために堆積量が減少, その結果として 表面の粗さが小さくなったと考察される。

この電極を用いて, $0.5 \mathrm{~mol} \cdot \mathrm{dm}^{-3} \mathrm{H}_{2} \mathrm{SO}_{4}+1 \mathrm{~mol} \cdot \mathrm{dm}^{-3}$ $\mathrm{CH}_{3} \mathrm{OH}$ 溶液中でのアルコール酸化活性を評価したものを 図 14 に示す。 $5 \mathrm{~Pa}$ で最も大きな電流密度が得られ，続いて $10 \mathrm{~Pa}$ であった。また, $0.5 \mathrm{~mol} \cdot \mathrm{dm}^{-3} \mathrm{H}_{2} \mathrm{SO}_{4}+1 \mathrm{~mol} \cdot \mathrm{dm}^{-3}$ $\mathrm{C}_{2} \mathrm{H}_{5} \mathrm{OH}$ 溶液に関しても同様に実験を行った結果, メタノー ル酸化活性と同じ傾向を示した。このアルコール酸化活性 も電気化学的な表面積の増減と同様の傾向を示したため, 電極面積が支配的であると推測される。

\section{4. むすび}

$\mathrm{Pt}-\mathrm{Ru}$ 電極触媒について，スパッ夕製膜条件と電極酸化 活性の関係を系統的に検討した。その結果は次のと抢りで ある。

（1）基板の違いがアルコール酸化活性に及ぼす影響は なく, Pt-Ru 層と基板には相互作用がないことが分かった。

(2) Pt-Ru 組成とアルコール酸化電流の関係について は, $\mathrm{Ru}$ 原子比 27〜 45 at.\%で最大の電流密度が得られた。

（3） スパッ夕時間を変えた条件については，製膜時間 を長くするほど (1 hr 以内), 得られる電流密度が大きくな ることがわかった。これはスパッ夕時間の増加に伴う, 電 極表面の粗さの増大に依存するところが大きく，二重層へ の充放電電流の電荷量と一致した。

（4） スパッ夕製膜時の $\mathrm{Ar}$ 圧力を変えると $\mathrm{Pt}-\mathrm{Ru}$ 原子 比が変化することが初めてわかり，さらに $5 \mathrm{~Pa}$ で最も大き な電流密度が得られた。これはスパッ夕製膜時の $\mathrm{Ar}$ 圧力 変化に伴う表面の粗さと一致した。

本研究は, 文部科学省, 産学官連携イノベーション創出 事業費補助金（独創的革新技術開発研究事業）の助成を受 けて実施した。

(平成 18 年 1 月 4 日受付，平成 18 年 3 月 29 日再受付)

\section{文献}

（1）携帯機器用燃料電池の実用化～構成材料における問題点と対応策， 技術情報協会 (2002)

(2) M. Watanabe and S. Motoo: "Electrocatalysis by ad-atoms part II enhancement of the oxidation of methanol on platinum by ruthenium ad-atoms", $J$. Electroanal. Chem., Vol.60, pp.267-273 (1975)
(3) M.-S. Löffler, H. Natter, R. Hempelmann, and K. Wippermann: "Preparation and characterisation of Pt-Ru model electrodes for the direct methanol fuel cell", Electrochim. Acta, Vol.48, pp.3047-3051 (2003)

(4) Z. Zhou, S. Wang, W. Zhou, L. Jiang, G. Wang, G. Sun, B. Zhou, and Q. Xin: "Preparation of highly active Pt/C cathode electrocatalysts for DMFCs by an improved aqueous impregnation method", Phys. Chem. Chem. Phys., Vol.5, No.24, pp.5485-5488 (2003)

(5) Y. Takasu, T. Kawaguchi, W. Sugimoto, and Y. Murakami: "Effects of surface area of carbon support on the characteristics of highly-dispersed Pt-Ru particles as catalysts for methanol oxidation", Electrochimica Acta, Vol.48, pp.3861-3868 (2003)

(6) T. Kawaguchi, W. Sugimoto, Y. Murakami, and Y. Takasu: "Particle growth behavior of carbon-supported Pt, Ru, PtRu catalysts prepared by an impregnation reductive-pyrolysis method for direct methanol fuel cell anodes", $J$. Catal., Vol.229, pp.176-184 (2005)

(7) M. Götz and H. Wendt: "Binary and ternary anode catalyst formulations including the elements W, Sn and Mo for PEMFCs operated on methanol or reformate gas", Electrochim. Acta, Vol.43, pp.3637-3644 (1998)

(8) J.-M. Leger: "Preparation and activity of mono- or bi-mitallic nanoparticles for electrocatalytic reactions", Electrochimica Acta, Vol.50, pp.3123-3129 (2005)

(9) Z. Liu, X.Y. Ling, X. Su, and J.Y. Lee: "Carbon-Supported Pt and PtRu Nanoparticles as Catalysts for a Direct Methanol Fuel Cell", J. Phys. Chem., Vol.108, pp.8234-8240 (2004)

(10) L. Dubau, C. Coutanceu, E. Garnier, J.-M. Leger, and C. Lamy: "Electrooxidation of methanol at platinum-Ruthenium catalysts prepared from colloidal precursors: Atomic composition and temperature effects", J. Appl. Electrochem., Vol.33, pp.419-429 (2003)

(11) M. Umeda, H. Ojima, M. Mohamedi, and I. Uchida: "Methanol electrooxidation at Pt-Ru-W sputter deposited on Au substrate", J. Power Sources, Vol.136, pp.10-15 (2004)

(12) T. Wook, S.-J. Park, L.E. Jones, M.F. Toney, K.-W. Park, and Y.-E. Sung: "Structure and Electrocatalysis of Sputtered RuPt Thin-Film Electrodes", $J$. Phys. Chem. B, Vol.109, pp.12845-12849 (2005)

(13) K.-W. Park and Y.-E. Sung: "Catalytic Activity of Platinum on Ruthenium Electrodes with Modified (Electro) chemical States", J. Phys. Chem. B, Vol.109, pp.13585-13589 (2005)

14) K.-W. Park, J.-H. Choi, K.-S. Ahn, and Y.-E. Sung: "PtRu Alloy and PtRu$\mathrm{WO}_{3}$ Nanocomposite Electrodes for Methanol Electrooxidation Fabricated by a Sputtering Deposition Method", J. Phys. Chem., Vol.108, pp.59895994 (2004)

(15) T. Yajima, H. Uchida, M. Watanabe: "In-Situ ATR-FTIR Spectroscopic Study of Electro-oxidation of Methanol and Adsorbed CO at Pt-Ru Alloy", J. Phys. Chem., Vol.108, pp.2654-2659 (2004)

(16) C. Pan, F. Dassenoy, M.-J. Casanove, K. Philippot, C. Amiens, P. Lecante, A. Mosset, and B. Chaudre: "A New Synthetic Method toward Bimetallic Ruthenium Platinum Nanoparticles; Composition Induced Structural Changes", J. Phys. Chem., Vol.103, pp.10098-10101 (1999)

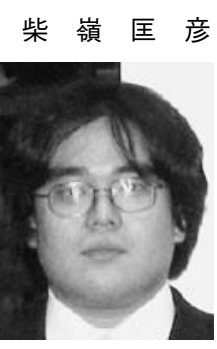

(非会員) 2004 年 3 月長岡技術科学大学工学部 卒業。同年 4 月長岡技術科学大学大学院工学研究 科材料開発工学専攻入学。

山田 明 文 (非会員) 1968 年 3 月東北大学大学院理学研究

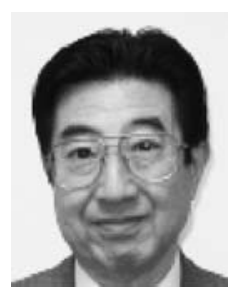
科化学専攻博士修了。同年 4 月日本学術振興会奨 励研究員, 東北大学助手を経て, 1981 年長岡技術 科学大学助教授, 1989 年同教授となり, 現在に至 る。理学博士。1970 年電気化学協会佐野進歩賞, 2001 年電気化学会北陸支部功労賞受賞。日本化 学会, 日本分析化学会, 電気化学会等会員。 
梅 田実 (正員) 1981 年 3 月東北大学大学院工学研究科応 用化学専攻修了。同年 4 月株式会社リコー入社。 2000 年東北大学大学院工学研究科助教授, 2002 年長岡技術科学大学助教授を経て, 2004 年同教授 となり, 現在に至る。工学博士。1995 年電子写真 学会研究奨励賞受賞。日本化学会, 電気化学会, 応用物理学会等会員。
田 中 正 治 (非会員) 1978 年 3 月東京理科大学理学部応用

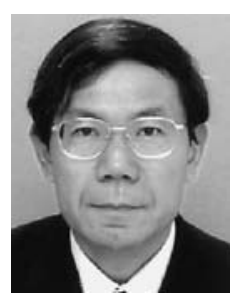
物理学科卒業。1980 年 3 月同大学大学院理学研 究科博士課程前期修了。同年 4 月日本真空技術 (株) 入社。1988 年 5 月 (株) リコー入社。主に 真空・薄膜プロセス技術, 薄膜材料の研究開発に 従事。2004 年より長岡技術科学大学客員教授, 現 在に至る。 